\title{
A cohort study on mortality among wives of workers in the asbestos cement industry in Casale Monferrato, Italy
}

\author{
Corrado Magnani, Benedetto Terracini, Cristiana Ivaldi, Mario Botta, Paola Budel, \\ Angelo Mancini, Roberto Zanetti
}

\begin{abstract}
The study investigates mortality from cancer and other diseases in a cohort of wives of asbestos cement workers in Casale Monferrato (northwest Italy). After the exclusion of women with an occupational record in the asbestos cement industry, the cohort comprised 1964 women. Their domestic exposure was estimated according to their husbands' periods of employment in the plant: $1740 \mathrm{had}$ a period of domestic exposure whereas the remaining 224 married an asbestos cement worker only after he definitely stopped his activity in the asbestos cement plant; these have, therefore, been considered as unexposed. The cohort of wives was constructed entirely through official records in the town offices and is both exhaustive and unaffected by recall bias. At the end of follow up (1988) 1669 women were alive, 270 were dead and 25 $(1 \cdot 2 \%)$ were untraced. Main mortality analyses were only up to age 79 to reduce the misclassification of causes of death. Expected mortality was based on local rates. Mortality analyses were limited to the period 1965-88 due to the availability of local rates: in that period 210 deaths occurred among women with domestic exposure $v 229 \cdot 1$ expected. There were four deaths from pleural tumours (one diagnosed as mesothelioma at necropsis) and six from lung cancer $v .0 .5$ and 4.0 expected respectively. Two further cases of mesothelioma were diagnosed by histological examination after the end of follow up. None of the three wives with histologically diagnosed mesothelioma had been engaged in
\end{abstract}

Cancer Epidemiology Unit, Local Health Authority and University, Torino, Italy

C Magnani, B Terracini, C Ivaldi

Special Project on Asbestos Cement, Local Health Authority, Casale Monferrato, Italy

M Botta, P Budel

Public Health Unit, Local Health Authority, Casale

Monferrato, Italy

A Mancini

Cancer Registry, Torino, Italy

R Zanetti industrial activities. Corresponding information for the other three cases could not be traced.

(British fournal of Industrial Medicine 1993;50:779-784)

The occurrence of malignant mesotheliomas after domestic exposure to asbestos has been shown, ${ }^{1-3}$ whereas only limited data on other malignancies have been published. ${ }^{4}$ The study by Anderson is the only one with a cohort design; all the others are either case-control studies on mesotheliomas or case reports. This can be attributed to the extreme difficulty of collecting a cohort of domestically exposed people without bias. Gardner and Saracci, who recently reviewed the subject, noticed the opportunity for further investigations. ${ }^{5}$

The largest Italian asbestos cement plant, belonging to the Italian Eternit Industries, operated in Casale Monferrato from 1907 to 1985 . We previously reported on a cohort study of the workforce in the plant. This showed a large increase in mortality from lung cancer (standardised mortality ratios (SMRs): 271 for men and 395 for women, both statistically significant), pleural tumours, and asbestosis in both sexes for the period 1964-86.6 The factory produced a large variety of asbestos cement products (flat and corrugated sheets, chimney tubes, and pipes). Both chrysotile and crocidolite were used throughout the period in which the factory was active. In 1980 crocidolite accounted for $10 \%$ of the asbestos used. No data are available for the previous years.

We have been able to assemble retrospectively an exhaustive cohort of women married to asbestos cement workers employed in the plant. The cohort was identified from town records and therefore is not affected by recall or selection biases. The cohort has been the subject of a retrospective mortality study which is described in the present paper.

Material and methods

Our previous study on asbestos cement workers in Casale Monferrato ${ }^{6}$ included 2604 men active in the plant on 1 January 1950 or subsequently enrolled. 
In Italy, individual data recorded in the offices of the town of residence include marital state, spouse's name, and other data essential for identification. This information is regularly updated, and transmitted to the town of the person's new residence in the case of movement. The same data are also retrospectively available for deceased subjects and include spouses who died or divorced.

Similar data are also recorded on the birth record, because the town of birth is notified of marriage, divorce, and death.

After a postal enquiry at the town where the cohort members were living at the end of the follow up we obtained satisfactory information on marital state (251 bachelors and 2347 married, divorced, or widower) for 2598 workers $(99 \cdot 8 \%)$. No information was found for the remaining six. Sixty three workers were married twice and one three times. At the end of these procedures the cohort comprised 2412 wives. Out of these, according to factory registers, 378 worked in the factory for a period between 1907 and 1985. These have been excluded from the cohort as well as 70 women who died before 1965 that is, the date of start of mortality analyses for the present study (of these 20 had died before 1950, date of start of follow up of the workers' cohort and 50 died or were lost to follow up in 1950-64). After these exclusions the cohort composed 1964 wives. In Italy women are registered in official records (including employer's records) only with their name at birth, even if married. To avoid possible mistakes, the linkage between this cohort and the lists of workers in Eternit has been repeated with different criteria and based also on the date of birth or husband's name. Relatives of mesothelioma cases have been interviewed by telephone to verify occupational history of the case.

Vital status of workers' wives was ascertained through the registrar's office of the town where the person was living. For each person the registrar's office was asked to certify whether she was alive or dead or had moved to another town. Causes of death were obtained from the town where death took place and coded according to the eighth revision of the International Classification of Diseases (ICD-8).

Duration of domestic exposure has been estimated according to husband's periods of employment in the plant. Total duration was computed as the sum of each working period after marriage. Date of first exposure was either the date of marriage or the date of first employment, whichever was the most recent. Latency has been computed since the date of first exposure.

Women lost to follow up were included in the computation of person-years until their last observation.

Expected numbers of deaths are based on mor- tality (age, period, and sex specific) in $1970-88^{7}$ in the provinces of Vercelli, Novara, Cuneo, Alessandria (where the town of Casale Monferrato is located), and Asti-that is, in Piedmont-excluding the province of Torino where over half the population lives in the metropolitan area of the city of Torino.

Mortality was analyed for the period 1965-88; expected figures in 1965-69 are based on rates in 1970-74. This led to the exclusion of person-years and deaths before 1965 .

Person-years of observation, expected numbers of deaths, SMRs, and their $95 \%$ confidence intervals (95\% CIs) were computed with the computer programme OCMAP-PC. ${ }^{8}$ Confidence intervals are based on the Poisson distribution of observed deaths.

\section{Results}

Table 1 describes the results of the follow up. At the end of follow up on 15 February 1988, 1669 women were alive, 270 were dead (for three of them the certified cause of death could not be traced), and 25 could not be traced (including 16 lacking essential data for the follow up).

Two hundred and twenty four women married asbestos cement workers after the men had definitely stopped working in the asbestos cement plant. These women are considered as unexposed and are referred to as women without domestic exposure throughout the rest of the paper and in the tables.

Table 2 presents observed and expected numbers of deaths for the major causes. The SMRs and 95\% CIs are limited to age 79 to reduce the chance of misclassification of the causes of death. Among women with domestic exposure, (as defined above)

Table 1 Descriptive data of the cohort of wives of asbestos cement workers in Casale Monferrato, Italy

\begin{tabular}{lrr}
\hline & $\begin{array}{l}\text { With } \\
\text { Domestic } \\
\text { Exposure }\end{array}$ & $\begin{array}{c}\text { Without } \\
\text { Domestic } \\
\text { Exposure }\end{array}$ \\
\hline No of women & 1740 & 224 \\
Lost to follow up & 6 & 3 \\
Lacking essential data for follow up & 11 & 5 \\
Alive on 15 February 1988 & 1461 & 208 \\
Dead (cause of death known) & 260 & 7 \\
Dead (cause of death unknown) & 2 & 1 \\
Person-years of observation & & \\
(1965-88) for age classes: & 1994 & 808 \\
$20-29$ & 6125 & 1199 \\
$30-39$ & 9406 & 864 \\
$40-49$ & 8260 & 251 \\
$50-59$ & 5046 & 70 \\
$60-69$ & 2586 & 60 \\
$70-79$ & 508 & 8 \\
$\geqslant 80$ & & \\
Total & 33925 & 3260 \\
\hline
\end{tabular}


total mortality and cancer mortality were close to the expected (210 observed $v 229 \cdot 1$ expected and $64 v 73.5$ respectively). After age 80 there were 52 observed deaths $v 65$ expected among women with domestic exposure and two $v$ one among women without exposure. The figure for women with domestic exposure includes 10 malignant neoplasms (one lung cancer) $v 6.7$ expected.

With the exception of pleural malignancies no cause of death occurred significantly more or less often than that expected.

Table 3 presents mortality from pulmonary and pleural neoplasms according to duration of exposure and latency from the first exposure for women with domestic exposure. No deaths were found before 10 years of latency and 10 years of exposure and no consistent trend with duration or latency occurred, but the table is based on small numbers.

Table 4 gives individual information on women dying from lung or pleural malignancy, including those who died when they were older than 80 or before 1965 and who were not included in the previous tables. Four deaths were attributed to pleural tumours: in one case the diagnosis was supported by a histological examination (subsequently confirmed at necropsy) and in two cases by radiological examinations. No data could be found for the remaining case. The table also includes two incident cases of mesothelioma (histologically diagnosed) found in an independent study on incidence of mesothelioma in the local Health Authority of Casale Monferrato. ${ }^{9}$ The first was diagnosed by histological examination in 1988 and died in 1989; the second was diagnosed in 1991 and is alive. Husbands of three cases (those histologically diagnosed) were interviewed by telephone: none of their wives was ever engaged in industrial activities. No relative could be found for the remaining cases.

Marriage is positively associated with health state. The association is conceptually similar to the selection bias known as the healthy worker effect. ${ }^{10}$ We examined the relation between mortality from major causes (all deaths, all malignancies, cardiovascular diseases, and respiratory diseases) and duration of marriage and latency, both computed from the wedding date. The analyses included every woman in the cohort, irrespective of domestic exposure and age at death (table 5). A reduction in mortality for married women was evident and persisted irrespective of time elapsed since marriage.

\section{Discussion}

Despite the well known association between asbestos and malignancies ${ }^{11}$ and the suggestions from case reports and case-control studies of mesotheliomas due to domestic exposure to asbestos ${ }^{5}$ only one cohort study has been published so far on mortality among family contacts of asbestos workers. Anderson ${ }^{4}$ analysed the mortality experience of women (wives and other relatives) living within the household of workers of an amosite factory in Paterson (USA). They found eight deaths from respiratory cancer (including two deaths from mesothelioma) $v 6.4$ expected. The excess was found only after 20 years of exposure

Table 2 Number of deaths before 80 years of age observed and expected in the cohort of wives of asbestos cement workers. The table is divided according to domestic exposure (see text)

\begin{tabular}{|c|c|c|c|c|c|c|c|c|}
\hline \multirow{2}{*}{$\begin{array}{l}\text { Cause of death } \\
\text { (ICD-8) }\end{array}$} & \multicolumn{4}{|c|}{ Women with domestic exposure } & \multicolumn{4}{|c|}{ Women without domestic exposure } \\
\hline & Obs & $\operatorname{Exp}$ & $S M R$ & $(95 \% C I)$ & Obs & $\operatorname{Exp}$ & $S M R$ & $(95 \% C I)$ \\
\hline $\begin{array}{l}\text { All causes }(000-999) \\
\text { All malignancies }(140-209) \\
\text { Gastrointestinal }(150-159) \\
\text { Stomach }(151) \\
\text { Colon and rectum }(153-154) \\
\text { Other }(150,155-159) \\
\text { Respiratory }(160-163) \\
\text { Lung }(162) \\
\text { Pleura (163) }\end{array}$ & $\begin{array}{r}210 \\
64 \\
22 \\
3 \\
14 \\
5 \\
10 \\
6 \\
4\end{array}$ & $\begin{array}{r}229 \cdot 1 \\
73 \cdot 5 \\
24 \cdot 5 \\
7 \cdot 2 \\
9 \cdot 9 \\
7 \cdot 4 \\
5 \cdot 0 \\
4 \cdot 0 \\
0 \cdot 5\end{array}$ & $\begin{array}{r}91 \cdot 7 \\
87 \cdot 1 \\
89 \cdot 8 \\
41 \cdot 7 \\
141 \cdot 2 \\
67 \cdot 6 \\
200 \cdot 4 \\
149 \cdot 8 \\
792 \cdot 3\end{array}$ & $\begin{array}{l}(79 \cdot 7-104 \cdot 9) \\
(67 \cdot 1-111 \cdot 3) \\
(56 \cdot 3-136 \cdot 0) \\
(8 \cdot 6-122 \cdot 0) \\
(77 \cdot 2-236 \cdot 9) \\
(21 \cdot 9-157 \cdot 7) \\
(96 \cdot 1-368 \cdot 5) \\
(55 \cdot 0-326 \cdot 1) \\
(215 \cdot 9-2028 \cdot 8)\end{array}$ & $\begin{array}{l}6 \\
1 \\
0 \\
0 \\
0 \\
0 \\
0 \\
0 \\
0\end{array}$ & $\begin{array}{l}7 \cdot 4 \\
2 \cdot 6\end{array}$ & $\begin{array}{l}81 \cdot 7 \\
38 \cdot 7\end{array}$ & $\begin{array}{r}(30 \cdot 0-177 \cdot 8) \\
(1 \cdot 0-215 \cdot 7)\end{array}$ \\
\hline $\begin{array}{l}\text { Breast }(174) \\
\text { Uterus }(180-182) \\
\text { Ovary }(183) \\
\text { Bladder }(188) \\
\text { Haemolymphatic (200-209) } \\
\text { Other malignancies } \\
\text { Diabetes (250) }\end{array}$ & $\begin{array}{r}10 \\
5 \\
6 \\
1 \\
4 \\
6 \\
5\end{array}$ & $\begin{array}{r}15 \cdot 5 \\
7 \cdot 3 \\
4 \cdot 0 \\
0 \cdot 9 \\
5 \cdot 1 \\
11 \cdot 2 \\
7 \cdot 9\end{array}$ & $\begin{array}{r}64 \cdot 6 \\
68 \cdot 2 \\
150 \cdot 6 \\
113 \cdot 8 \\
78 \cdot 7 \\
53 \cdot 6 \\
63 \cdot 3\end{array}$ & $\begin{array}{l}(31 \cdot 0-118 \cdot 9) \\
(22 \cdot 1-159 \cdot 2) \\
(55 \cdot 3-327 \cdot 8) \\
(2 \cdot 8-634 \cdot 0) \\
(21 \cdot 4-201 \cdot 5) \\
(19 \cdot 7-116 \cdot 6) \\
(20 \cdot 1-147 \cdot 8)\end{array}$ & $\begin{array}{l}1 \\
0 \\
0 \\
0 \\
0 \\
0 \\
0\end{array}$ & 0.7 & $152 \cdot 5$ & $(3 \cdot 8-849 \cdot 9)$ \\
\hline $\begin{array}{l}\text { Cardiovascular }(390-459) \\
\text { Respiratory (460-519) } \\
\text { Digestive diseases (520-577) } \\
\text { Liver cirrosis (571) } \\
\text { External causes (800-999) } \\
\text { Poorly defined (780-799) } \\
\text { Unknown (in all causes category) }\end{array}$ & $\begin{array}{r}87 \\
9 \\
18 \\
11 \\
4 \\
7 \\
2\end{array}$ & $\begin{array}{r}97 \cdot 5 \\
9 \cdot 6 \\
14 \cdot 2 \\
7 \cdot 6 \\
10 \cdot 2 \\
2 \cdot 0\end{array}$ & $\begin{array}{r}89 \cdot 2 \\
94 \cdot 1 \\
126 \cdot 5 \\
145 \cdot 1 \\
39 \cdot 1 \\
356 \cdot 3\end{array}$ & $\begin{array}{c}(71 \cdot 5-110 \cdot 0) \\
(43 \cdot 0-178 \cdot 7) \\
(75 \cdot 0-199 \cdot 9) \\
(72 \cdot 4-259 \cdot 6) \\
(10 \cdot 6-100 \cdot 1) \\
(143 \cdot 2-734 \cdot 2)\end{array}$ & $\begin{array}{l}4 \\
0 \\
0 \\
0 \\
0 \\
0 \\
1\end{array}$ & $2 \cdot 5$ & $162 \cdot 1$ & $(43 \cdot 9-412 \cdot 8)$ \\
\hline
\end{tabular}


Table 3 Distribution of pulmonary and pleural neoplasms before 80 years of age according to latency and duration of domestic exposure in the cohort of wives of asbestos cement workers. The table includes only women with domestic exposure

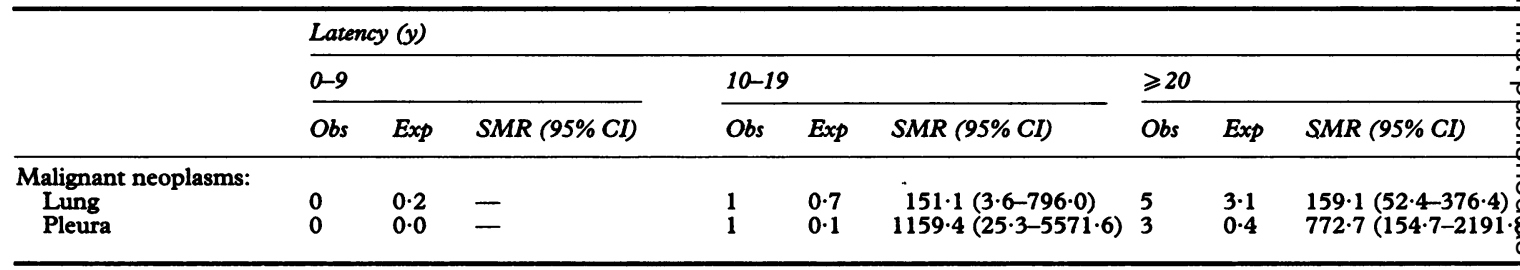

(eight observed $v 4 \cdot 7$ expected). Results were not presented separately for wives and for the other relatives.

A survey of amounts of contamination with airborne asbestos in workers' homes was presented by Nicholson et al. ${ }^{12}$ They found a concentration of asbestos in the range $50-5000 \mathrm{ng} / \mathrm{m}^{3}$ of air with a median between 100 and $200 \mathrm{ng} / \mathrm{m}^{3}$. Those concentrations were higher compared with those found in buildings with asbestos insulation or schools with damaged asbestos surfaces.
In our study we focused on the mortality of wives of workers employed in the Eternit plant of Casale Monferrato. ${ }^{6}$ No data are available on asbestos exposure within their homes. The cohort of their husbands showed a large excess of respiratory cancers and asbestosis, however. No laundering facility was ever available within the plant, and it was customary to leave the plant in working clothes.

In our present study the list of women to be included in the cohort was reconstructed entirely through official records in the town offices and

Table 4 Main data on wives of asbestos cement workers who died from pleural or pulmonary cancer. The table also includes women excluded from statistical analyses

\begin{tabular}{|c|c|c|c|c|c|c|c|}
\hline No & $\begin{array}{l}\text { Cause of } \\
\text { death } \\
\text { (ICD-8) }\end{array}$ & $\begin{array}{l}\text { Year of } \\
\text { birth }\end{array}$ & $\begin{array}{l}\text { Year of } \\
\text { death }\end{array}$ & $\begin{array}{l}\text { Duration } \\
\text { of } \\
\text { exposure (y) }\end{array}$ & $\begin{array}{l}\text { Latency } \\
(y)\end{array}$ & Age (y) & Notes \\
\hline $\begin{array}{l}1 \\
2 \\
3 \\
4 \\
5 \\
6 \\
7\end{array}$ & $\begin{array}{l}162 \cdot 1 \\
162 \cdot 1 \\
163.0 \\
162 \cdot 1 \\
162 \cdot 1 \\
162 \cdot 1 \\
162 \cdot 1\end{array}$ & $\begin{array}{l}1929 \\
1920 \\
1913 \\
1906 \\
1935 \\
1902 \\
1895\end{array}$ & $\begin{array}{l}1986 \\
1983 \\
1967 \\
1986 \\
1968 \\
1956 \\
1975\end{array}$ & $\begin{array}{r}20 \cdot 5 \\
15.7 \\
11 \cdot 3 \\
17 \cdot 1 \\
11.8 \\
4.4 \\
6.3\end{array}$ & $\begin{array}{r}26 \cdot 0 \\
24 \cdot 4 \\
11 \cdot 3 \\
39 \cdot 1 \\
11 \cdot 8 \\
4 \cdot 4 \\
26 \cdot 1\end{array}$ & $\begin{array}{l}56 \cdot 7 \\
63 \cdot 2 \\
54 \cdot 1 \\
79.9 \\
33 \cdot 0 \\
53 \cdot 9 \\
80.7\end{array}$ & $\begin{array}{l}\text { Died before analysis period } \\
\text { Died after } 80 \text { years of age; pleural malignancy } \\
\text { suspected }\end{array}$ \\
\hline $\begin{array}{r}8 \\
9 \\
10 \\
11 \\
12 \\
13\end{array}$ & $\begin{array}{l}162.1 \\
162.1 \\
162.1 \\
163.0 \\
163.0 \\
163.0\end{array}$ & $\begin{array}{l}1901 \\
1894 \\
1917 \\
1908 \\
1912 \\
1925\end{array}$ & $\begin{array}{l}1964 \\
1960 \\
1987 \\
1979 \\
1984 \\
1985\end{array}$ & $\begin{array}{l}19 \cdot 9 \\
11 \cdot 2 \\
20.6 \\
32 \cdot 3 \\
14.5 \\
12.9\end{array}$ & $\begin{array}{l}19 \cdot 9 \\
17 \cdot 3 \\
33 \cdot 8 \\
50 \cdot 2 \\
30 \cdot 4 \\
29 \cdot 6\end{array}$ & $\begin{array}{l}62 \cdot 9 \\
65 \cdot 6 \\
69 \cdot 7 \\
70 \cdot 9 \\
72 \cdot 7 \\
59 \cdot 2\end{array}$ & $\begin{array}{l}\text { Mesothelioma histologically diagnosed in } 1983 \\
\text { and verified at necropsy }\end{array}$ \\
\hline $\begin{array}{l}14 \\
15\end{array}$ & $\begin{array}{l}162 \cdot 1 \\
163 \cdot 0\end{array}$ & $\begin{array}{l}1936 \\
1916\end{array}$ & $\begin{array}{l}1987 \\
1989\end{array}$ & $\begin{array}{l}28 \cdot 1 \\
14 \cdot 0\end{array}$ & $\begin{array}{l}31 \cdot 4 \\
42 \cdot 0\end{array}$ & $\begin{array}{l}51 \cdot 6 \\
73 \cdot 0\end{array}$ & $\begin{array}{l}\text { Mesothelioma histologically diagnosed in } 1988 . \\
\text { Death from mesothelioma after the end of the } \\
\text { follow up in 1989: no necropsy. }\end{array}$ \\
\hline 16 & 163.0 & 1919 & alive & 23.0 & $46 \cdot 0$ & alive & $\begin{array}{l}\text { Mesothelioma histologically diagnosed in 1991; } \\
\text { alive at the end of follow up }\end{array}$ \\
\hline
\end{tabular}

Table 5 Cohort of wives of asbestos cement workers. Distribution of deaths, total and for some major causes, according to latency computed from marriage. The table includes also women dying at 80 or older

\begin{tabular}{|c|c|c|c|c|c|c|}
\hline & \multicolumn{6}{|c|}{ Latency (y) } \\
\hline & \multicolumn{3}{|l|}{$0-9$} & \multicolumn{3}{|c|}{$10-19$} \\
\hline & Obs & $\operatorname{Exp}$ & SMR $(95 \% C I)$ & Obs & $\operatorname{Exp}$ & $\operatorname{SMR}(95 \% C I)$ \\
\hline $\begin{array}{l}\text { All causes } \\
\text { All malignancies } \\
\text { Cardiovascular disease } \\
\text { Respiratory disease }\end{array}$ & $\begin{array}{l}7 \\
2 \\
1 \\
1\end{array}$ & $\begin{array}{l}8 \cdot 4 \\
2 \cdot 6 \\
2 \cdot 3 \\
0 \cdot 3\end{array}$ & $\begin{array}{l}83 \cdot 8(33 \cdot 7-172 \cdot 7) \\
78 \cdot 0(9 \cdot 4-281 \cdot 7) \\
42 \cdot 8(1 \cdot 1-238 \cdot 7) \\
337 \cdot 8(8 \cdot 4-1882)\end{array}$ & $\begin{array}{r}18 \\
8 \\
4 \\
0\end{array}$ & $\begin{array}{r}20.6 \\
8 \cdot 0 \\
5 \cdot 6 \\
0.7\end{array}$ & $\begin{array}{l}87 \cdot 4(51 \cdot 8-138 \cdot 1) \\
99 \cdot 8(43 \cdot 1-196 \cdot 6) \\
71 \cdot 9(19 \cdot 6-184 \cdot 2) \\
-\end{array}$ \\
\hline
\end{tabular}




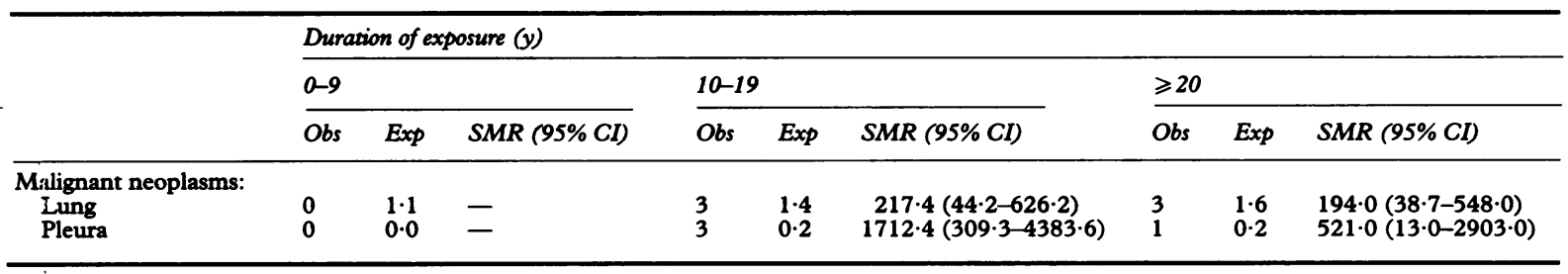

selection or recall bias are unlikely. Marital state has been successfully ascertained for 2598 male workers out of 2604. The proportion of bachelors at each age category was similar to the corresponding proportion reported at the 1981 census for the Province of Alessandria, ${ }^{13}$ where most cohort members lived.

The proportion of wives successfully traced at follow up was 2387 out of 2412. Sixteen women could not be followed up because of insufficient data.

Women with occupational exposure in the Eternit plant were identified and excluded from the cohort on the basis of official records in the plant. Other opportunities for occupational exposure to asbestos in the area are unlikely, as no other asbestos industries of any relevance existed in the town. ${ }^{14}$

Expected figures are based on local death rates. Main analyses excluded subjects over 80 years of age, to improve the overall quality of death certification.

Except for pleural neoplasms, mortality among women with the opportunity for exposure to domestic asbestos was not statistically different from that expected for any of the causes of death considered. Findings on lung tumours are based on figures so small that no further discussion is warranted. The relevant clinical record could be examined for three cases of pleural tumour out of four dying within the study period: in one case it included a histological diagnosis of epithelioid mesothelioma (confirmed at necropsy) and in the remaining two cases the diagnosis was of primitive pleural malignancy based on radiological examinations. Two more cases of mesothelioma (histologically diagnosed) were found after the closure of the follow up.

All women reported to have a pleural cancer and all but two of those dying from lung cancer had been exposed for at least 10 years. Beyond this period risks were not related to duration of exposure or latency but this result is not conclusive given the small numbers involved. The cases histologically diagnosed had 13,14 , and 23 years of exposure and 30,42, and 46 years of latency respectively.

In conclusion this study found a clear excess of mesotheliomas among wives of workers in the asbestos cement production industry. Although there is some uncertainty due to the low proportion of cases submitted to necropsy (one of six), three out of six diagnoses were based on histological examination. This can be considered as an acceptable diagnostic standard, because most pathologists nowadays are sufficiently confident of biopsy based diagnoses.

Our results are in agreement with the only similar study published before and confirm the importance of avoiding contamination of asbestos workers' homes.

The study was supported in part by research grants from The Commission of European Communities (Europe Against Cancer Project), Regione Piemonte (Progetto Obbiettivo CementoAmianto), CSI-Piemonte, Associazione Italiana per la Ricerca sul Cancro, and the International Agency for Research on Cancer.

\begin{tabular}{|c|c|c|c|c|c|c|}
\hline & \multicolumn{6}{|c|}{ Latency $(y)$} \\
\hline & \multicolumn{3}{|c|}{$20-9$} & \multicolumn{3}{|l|}{$\geqslant 30$} \\
\hline & Obs & $\operatorname{Exp}$ & $\operatorname{SMR}(95 \% C I)$ & $O b s$ & $\operatorname{Exp}$ & $\operatorname{SMR}(95 \% C I)$ \\
\hline $\begin{array}{l}\text { All causes } \\
\text { All malignancies } \\
\text { Cardiovascular disease } \\
\text { Respiratory disease }\end{array}$ & $\begin{array}{r}33 \\
12 \\
11 \\
0\end{array}$ & $\begin{array}{r}40 \cdot 1 \\
16 \cdot 6 \\
12 \cdot 5 \\
1 \cdot 3\end{array}$ & $\begin{array}{l}82 \cdot 3(56 \cdot 6-115 \cdot 6) \\
72 \cdot 1(37 \cdot 3-126 \cdot 0) \\
88 \cdot 2(44 \cdot 0-157 \cdot 8) \\
-\end{array}$ & $\begin{array}{l}212 \\
53 \\
103 \\
11\end{array}$ & $\begin{array}{r}235 \cdot 8 \\
56 \cdot 3 \\
121 \cdot 7 \\
11 \cdot 5\end{array}$ & $\begin{array}{l}89 \cdot 9(78 \cdot 2-102 \cdot 9) \\
94 \cdot 2(70 \cdot 6-123 \cdot 2) \\
84 \cdot 7(69 \cdot 1-102 \cdot 7) \\
95 \cdot 3(47 \cdot 6-170 \cdot 6)\end{array}$ \\
\hline
\end{tabular}


We acknowledge the contribution from clerks in municipality offices who made this study possible and from Marinella Nonnato, from our staff, who took care of the follow up procedures.

Requests for reprints to: Dr Corrado Magnani, Servizio Universitario di Epidemiologia dei Tumori, USL Torino 8, Via Santena 7, 10126 Torino, Italy.

1 Wagner JC, Sleggs CA, Marchand P. Diffuse pleural mesothelioma and asbestos exposure in the north western Cape Province. Br F Ind Med 1960;17:260-71.

2 Newhouse MA, Thompson H. Mesothelioma of pleura and peritoneum following exposure to asbestos in the London Area. Br F Ind Med 1965;22:261-9.

3 Vianna NJ, Polan AK. Non-occupational asbestos exposure and malignant mesothelioma in females. Lancet 1987;i: 1061-3.

4 Anderson $\mathrm{H}$. Family contact exposure. In: Proceedings of the world symposium on asbestos. Montreal 25-27 May 1982. Montreal: Canadian Asbestos Information Centre, 1982; 349-62.
5 Gardner M, Saracci R. Effects on health of non-occupational exposure to airborne asbestos fibres. In: Bignon J, Peto J, Saracci R, eds. Non-occupational exposure to mineral fibres. Lyon: IARC, 1989;375-97. (IARC publ 90.)

6 Magnani C, Terracini B, Bertolone GP, et al. Mortalitá per tumori e altre malattie del sistema respiratorio tra i lavoratori del cemento-amianto a Casale Monferrato. Uno studio di coorte storico. Med Lav 1987;78:441-53.

7 Capocaccia R, Farchi G, Mariotti S, et al. La mortalitá in Italia nel periodo 1970-9. Roma: Istituto Superiore di Sanitá, 1984. (Rapporto Istsan 84/10.)

8 Marsh G. Occupational mortality analysis program-OCMAP V.2.O. Operating manual. Pittsburgh University of Pittsburgh, 1989.

9 Magnani C., Borgo G., Betta G.P., et al. Mesothelioma and non-occupational environmental exposure to asbestos. Lancet 1991;338:50.

10 McMichael AJ. Standardized mortality ratios and the "Healthy worker effect": scratching beneath the surface $f$ Occup Med 1976;18:165-8.

11 International Agency for Research on Cancer. Monographs on the evaluation of carcinogenic risks to humans. Supplement 7 : Overall evaluations of carcinogenicity: An updating of LARC Monographs Vol 1-42. Lyon: IARC, 1987; 106-17.

12 Nicholson WJ, Rohl AN, Weisman I, Selikoff IJ Environmental asbestos concentration in the United States. In: Wagner JC, ed. Biological effects of mineral fibres. Lyon: International Agency for Research on Cancer, 1980. (Sci publ. 30.)

13 ISTAT. 120 Censimento Generale della Popolazione. 25 Ottobre 1981. Provincia di Alessandria. Roma: ISTAT, 1984.

14 Magnani C, Borgo G, Betta GP, et al. Mesothelioma and nonoccupational environmental exposure to asbestos. Lancet 1991;338:949.

Accepted 19 October 1992

\section{Vancouver style}

All manuscripts submitted to the $B r f$ Ind Med should conform to the uniform requirements for manuscripts submitted to biomedcical journals (known as the Vancouver style.)

The $B r f$ Ind Med, together with many other international biomedical journals, has agreed to accept articles prepared in accordance with the Vancouver style. The style (described in full in $\mathrm{Br}$ f Ind Med, 24 February 1979, p 532) is intended to standardise requirements for authors.

References should be numbered consecutively in the order in which they are first mentioned in the test by Arabic numerals above the line on each occasion the reference is cited (Manson ${ }^{1}$ confirmed other reports ${ }^{2-5} \ldots$. .). In future references to papers submitted to the $\mathrm{Br} \mathcal{F}$ Ind $\mathrm{Med}$ should include: the names of all authors if there are six or less or, if there are more, the first three followed by et al; the title of journal articles or book chapters; the titles of journals abbreviated according to the style of Index Medicus; and the first and final page numbers of the article or chapter.

Examples of common forms of references are:

1 International Steering Committee of Medical Editors, Uniform requirements for manuscripts submitted to biomedical journals. Br f Ind Med 1979;1:532-5.

2 Soter NA, Wasserman SI, Austen KF. Cold urticaria: release into the circulation of histamine and eosinophil chemotactic factor of anaphylaxis during cold challenge. $N$ Engl $f$ Med 1976;294:687-90.

3 Weinstein L, Swartz MN. Pathogenic properties of invading micro-organisms. In: Soderman WA Jr, Soderman WA, eds. Pathologic physiology, mechanisms of disease. Philadelphia: W B Saunders, 1974:457-72. 